red. prof. dr. sc. Lajoš Žager

Sveučilište u Zagrebu, Ekonomski fakultet, Zagreb, Republika Hrvatska lzager@efzg.hr

doc. dr. sc. Ana Ježovita

Sveučilište u Zagrebu, Ekonomski fakultet, Zagreb, Republika Hrvatska ajezovita@efzg.hr

\title{
UTJECAJ STRUKTURE IMOVINE PODUZEĆA NA OCJENU LIKVIDNOSTI
}

\author{
Pregledni rad
}

\section{Sažetak}

U današnjim uvjetima poslovanja koje je zahvaćeno nepovoljnim gospodarskim okruženjem i općom nelikvidnosti posebno dolazi do izražaja sposobnost poduzeća da pravovremeno dolazi do adekvatnih iznosa novca potrebnih za podmirenje dospjelih obveza. Najznačajniji izvor novčanih priljeva za svako poduzeće je obavljanje njegove osnovne djelatnosti koja se ostvaruje prodajom, bilo usluga, roba ili proizvoda. Kao posljedica primjene obračunske osnove u računovodstvenoj evidenciji poslovnih događaja dolazi do nastanka prihoda neovisno o tome da li je novac primljen u trenutku prodaje ili je prodaja provedena uz odgodu plaćanja. Kao posljedica prodaje uz odgodu plaćanja nastaju potraživanja od kupaca, a tek naplatom tih potraživanja poduzeće raspolaže s potrebnim novčanim sredstvima za podmirenje dospjelih obveza. Upravo kroz takvu interpretaciju poslovnog ciklusa istaknuta je važnost svih oblika kratkotrajne imovine za upravljanje novčanim jazom i za ocjenu likvidnosti. Pored toga, važno je uvažavati veličinu poduzeća, djelatnost $i$ geografsko područje djelovanja. Tradicionalni financijski pokazatelji likvidnosti kao što su koeficijent ubrzane likvidnosti, koeficijent tekuće likvidnosti i koeficijent financijske stabilnosti imaju važnu ulogu u ocjeni sposobnosti poduzeća da podmiruje kratkoročne obveze, ali uvođenjem dodatne dimenzije ocjene učinkovitosti upravljanja kratkotrajnom imovine dolazi se do obuhvatnijih zaključaka o financijskom položaju i sigurnosti poslovanja poduzé́a.

Ključne riječi: struktura imovine, likvidnost, solventnost, novčani jaz

JEL: M41, G32 


\section{UVOD}

Jedno od temeljnih pitanja svakog poduzeća, neovisno o njegovoj veličini, je pitanje vrijednosti, količine i strukture njegove imovine. Nedvojbeno je da vrste imovine koje pojedino poduzeće ima kao i struktura te imovine ovise o djelatnosti koju obavlja. U tome smislu pri definiranju poželjne strukture imovine potrebno je uvažavati specifičnosti samog poduzeća kao što su djelatnost, veličina, makroekonomsko okruženje, pravni i porezni regulatorni okvir te geografsko područje djelovanja. Navedeni faktori značajni su za djelovanje poduzeća u cjelini, a pri tome i za politiku upravljanja imovinom poduzeća. Imovina je resurs poduzeća. Predmet ovog rada uključuje razradu vrsta imovine i alata relevantnih za ocjenu likvidnosti poduzeća kao i utvrđivanje likvidnosne situacije u Republici Hrvatskoj. U skladu s navedenim predmetom moguće je razraditi ciljeve koji su obuhvaćeni ovim radom, a ti su: (a) sistematizacija odrednica koje imaju značaj za ocjenu likvidnosti poduzeća; (b) pregled alata koji se uobičajeno primjenjuju za ocjenu likvidnosti poduzeća; (c) analiza likvidnosti srednje velikih i velikih poduzeća realnog sektora u Republici Hrvatskoj. Pri pisanju rada korištene su deskriptivna i induktivna metoda, metoda analize, apstrakcije, klasifikacije, kompilacije, kao i metoda uzorka i statistička metoda. Za izradu rada korištene su relevantne znanstvene knjige i članci kao i baze podataka (Državni zavod za statistiku i Financijska agencija).

\section{STRUKTURA IMOVINE KAO ODREDNICA OCJENE LIKVIDNOSTI}

Poduzeće svoje resurse mora koristiti za obavljanje osnovne djelatnosti pri čemu se može govoriti o uvjetu da se od imovine poduzeća moraju očekivati buduće ekonomske koristi (Žager et al., 2017., 93.). „Buduća ekonomska korist utjelovljena u imovini jest potencijal da se doprinese, izravno ili neizravno, priljevu novca i novčanih ekvivalenata kod poduzetnika.“ (Okvir za primjenu Hrvatskih standarda financijskog izvještavanja, točka 1.4.) Prema Hrvatskim standardima financijskog izvještavanja stvaranje budućih ekonomskih koristi ostvaruje se pojedinačnom ili kombiniranom upotrebom raspoloživih resursa za proizvodnju proizvoda namijenjenih prodaji te prodaju roba ili usluga, a pored osnovne djelatnosti ekonomske koristi mogu se ostvariti razmjenom resursa, upotrebom za podmirivanje obveza ili raspodjelom vlasnicima (Okvir za primjenu Hrvatskih standarda financijskog izvještavanja, točka 1.4.).

Važnost ekonomskih koristi u kontekstu imovine naglašena je kroz same definicije prihoda i rashoda koji nastaju kao posljedica obavljanja djelatnosti poduzeća. S jedne strane prihodi su povećanje, a s druge strane rashodi su smanjenje 
ekonomskih koristi što sveukupno utječe na promjenu vlastitih izvora financiranja, a za to je presudna adekvatna struktura imovine koje je usmjerena generiranju budućih ekonomskih koristi. Nastanak prihoda neizostavan je s aspekta koncepta vremenske neograničenosti poslovanja. Prihodi rezultiraju novčanim priljevima neophodnima za podmirenje obveza. U tome smislu, ukoliko se imovina ne koristi za stvaranje budućih ekonomskih koristi, to rezultira samo nastankom negativne komponente, rashoda, što u konačnici utječe na smanjenje vlastitih izvora financiranja. Takav razvoj situacije negativno utječe na ukupnu strukturu izvora financiranja, nepostojanost priljeva za podmirenje obveza koje u konačnici vodi nelikvidnosti i insolventnosti.

Prema aktualnom Zakonu o računovodstvu mikro, mala i srednje velika poduzeća dužna su sastavljati i prezentirati godišnje financijske izvještaje primjenom $\mathrm{Hr}-$ vatskih standarda financijskog izvještavanja, velika poduzeća, subjekti od javnog interesa i financijske institucije primjenom Međunarodnih standarda financijskih izvještavanja (Zakon o računovodstvu, Narodne novine broj 78/2015, 134/2015, 120/2016, članak 17.). Da bi se neki resurs mogao priznati kao imovina u izvještaju o financijskom položaju treba imati trošak ili vrijednost koja se može pouzdano izmjeriti te treba biti vjerojatno da će buduće ekonomske koristi povezane s tom imovinom pritjecati u poduzeće (Okvir za primjenu Hrvatskih standarda financijskog izvještavanja, točka 1.6.).

Za ocjenu likvidnosti i solventnosti poduzeća važnu ulogu ima klasifikacija imovine i izvora imovine prema ročnosti gdje se razlikuje kratkoročnost od dugoročnosti. Ako se od imovine očekuje da će se realizirati, prodati ili potrošiti tijekom redovnog poslovnog ciklusa u roku od dvanaest mjeseci tada će se klasificirati kao kratkotrajna imovina, odnosno obveze za koje se očekuje da će se podmiriti unutar dvanaest mjeseci klasificirat će se kao kratkoročne obveze (Međunarodni standardi financijskog izvještavanja, točke od 66. do 76.)

Prema Pravilniku o strukturi i sadržaju godišnjih financijskih izvještaja (Narodne novine br. 95/2016, Prilog I) kratkotrajna imovina poduzeća se sistematizira prema kriteriju rastuće likvidnosti prema funkciji koju obavlja u poduzeću na $Z a-$ lihe, Potraživanja, Kratkotrajna financijska imovina ili Novac u banci i blagaj$n i$. Pored navedenog kratkotrajna imovina poduzeća može uključivati i plaćene troškove budućeg razdoblja i obračunate prihode. Struktura imovine razlikuje se kod različitih poduzeća i u ovisnosti je o ranije navedenim odrednicama. Međutim, moguće je utvrditi određenu uobičajenu strukturu u ovisnosti o djelatnosti poduzeća. Neovisno o svojoj djelatnosti za sva je poduzeća uobičajeno da imaju određeni udio potraživanja u strukturi kratkotrajne imovine. Poduzeća koja se bave trgovinom u strukturi kratkotrajne imovine imaju značajne udjele zaliha trgovačke robe, dok s druge strane za proizvodna poduzeća je uobičajeno da u 
kratkotrajnoj imovini imaju zalihe sirovina i materijala, nedovršene proizvodnje i gotovih proizvoda. Nadalje, u ovisnosti o trajanju poslovnog ciklusa može se govoriti o obrascima udjela pojedinih oblika zaliha i drugih oblika kratkotrajne imovine. Sve navedeno navodi na zaključak da pri analizi likvidnosti poduzeća treba u obzir uzeti i brojne druge odrednice osim očekivanih vrijednosti pokazatelja te analizi svakog poduzeća potrebno je pristupiti individualno.

\section{UOBIČAJENI ALATI ZA OCJENU SPOSOBNOSTI PODMIRIVANJA OBVEZA PODUZEĆA}

Pitanje sposobnosti poduzeća da pravovremeno podmiruje svoje obveze uvijek je aktualno. Vezano za navedenu 'sposobnost' vežu se pojmovi likvidnosti i solventnosti. Likvidnost se uobičajeno definira kao sposobnost poduzeća da pravovremeno podmiruje svoje dospjele kratkoročne obveze. Za likvidnost se još ističe da predstavlja sposobnost unovčavanja odnosno kao sposobnost imovine da se neometano izmjenjuje u poslovnom (operativnom) ciklusu (Tintor, 2009., 512.). „Analiza likvidnosti mjeri sposobnost poduzeća da ispuni svoje kratkoročne obveze. Likvidnost mjeri brzinu pretvaranja kratkotrajne imovine u novac" (Robinson et al., 2009., 284.). „Ako poduzeće može odgoditi odljeve novca dobavljačima, zaposlenima i ostalima do razdoblja priljeva novca od kupaca te ako primi više novca nego što mora isplatiti, poduzeće se vjerojatno neće susresti s problemima s likvidnosti“ (Wahlen et al., 2011., 361.). S druge strane za solventnost se često ističe da predstavlja platežnu sposobnost poduzeća.

Solventnost (engl. solvency) je sposobnost poduzeća da raspoloživim novčanim sredstvima podmiri sve obveze odnosno situacija u kojoj je imovina poduzeća veća od njegovih dugova (Anić, Goldstein, n.d.). „Solventnost se odnosi na sposobnost poduzeća da ispuni svoje dugoročne obveze" (Robinson et al., 2009., 288.). „Solventnost se razumijeva kao sposobnost zaštite od rizika likvidnosti i stečaja i kao zaštita te sposobnosti na dugi rok“ (Tintor, 2009., 553.). „Pokazatelji upotrebe poluge ukazuju na relativnu zaduženost poduzeća ili na teret kamata i drugih fiksnih izdataka za naknade financijerima u ukupnoj dobiti, oni predstavljaju svojevrsnu mjeru stupnja rizika ulaganja u analizirano poduzeće“ (Orsag, 1997., 208.).U kontekstu solventnosti naglasak je na sposobnosti poduzeća da upravlja tuđim izvorima financiranja odnosno da plaća sve svoje obveze (kratkoročne i dugoročne) o njihovim dospijeću te se još naziva tehničkom solventnošću (Tintor, 2009., 550.). Pored tehničke solventnosti može se govoriti o stvarnoj solventnosti kao situaciji u kojoj vrijednost imovine je veća od vrijednosti ukupnih tuđih izvora financiranja (Tintor, 2009., 550.). U kontekstu analize solventnosti u literaturi se često govori o analizi zaduženosti. 
Suprotan pojam solventnosti je insolventnost. Insolventnost predstavlja situaciju koja poduzeće vodi u stečaj, a realizira se ostvarivanjem gubitaka koji premašuju vrijednost kapitala (vlastitih izvora financiranja koji time postaju negativni), a u tome slučaju obveze premašuju vrijednost imovine. U takvoj situaciji, poduzeće nema dovoljno imovine za podmirivanje svojih ukupnih obveza (tuđih izvora financiranja), a vlasnici poduzeća imaju negativan ostatak vrijednosti (knjigovodstvena vrijednost poduzeća je negativna).

Ocjena likvidnosti i solventnosti poduzeća uobičajeno se provodi izračunom relevantni pokazatelja na temelju informacija raspoloživih iz bilance i računa dobiti i gubitka. Iako je pojedinačne pokazatelje moguće sistematizirati u različite skupine i podskupine, generalno se može govoriti s jedne strane o pokazateljima likvidnosti, a s druge strane o pokazateljima solventnosti (zaduženosti). I pokazatelji likvidnosti i pokazatelji zaduženosti mogu se promatrati sa statičkog i dinamičkog aspekta (Tablica 1).

Tablica 1. Pokazatelji likvidnosti i zaduženosti

\begin{tabular}{|c|c|c|}
\hline & LIKVIDNOST & ZADUŽENOST \\
\hline STATIČKA & Koeficijent trenutne likvidnosti & Koeficijent zaduženosti \\
& $\begin{array}{c}\text { Koeficijent ubrzane likvidnosti } \\
\text { Koeficijent tekuće likvidnosti }\end{array}$ & Koeficijent vlastitog financiranja \\
& Koeficijent financiranja \\
\hline DINAMIČKA & Novčani jaz & Pokriće troškova kamata \\
\hline
\end{tabular}
Izvor: autori prilagodili prema Žager et al., 2017.; Tintor, 2009.

Statičkim pokazateljima likvidnosti ocjenjuje se sposobnost poduzeća da podmiruje svoje obveze s aspekta vrijednosti iz izvještaja o financijskom položaju (bilance). Koeficijentom trenutne likvidnosti ocjenjuje se koliko je obveza poduzeće u mogućnosti podmiriti u trenutku sastavljanja bilance. „Analitičar rijetko koeficijentu trenutne likvidnosti pridaje veliku važnost kada ocjenjuje likvidnost poduzeća jer nije realno očekivati da poduzeće ima dovoljno novčanih ekvivalenata i utrživih vrijednosnica da pokrije kratkoročne obveze" (Gibson, 2011., 226.). „Analitičar bi trebao razmatrati koeficijent trenutne likvidnosti kod poduzeća koja po prirodi imaju sporo obrtanje zaliha i potraživanja te kod poduzeća čije poslovanje je vrlo špekulativne prirode“ (Gibson, 2011., 226.). Koeficijent trenutne likvidnosti ,predstavlja pouzdanu mjeru likvidnosti pojedinog poduzeća u kriznim situacijama“ (Robinson et al., 2009., str. 286.). „Pokazatelj je koristan u situacijama kada poduzeće ima problema s naplatom potraživanja“ (Friedlob \& Schleifer, 2003., 75.). Važno je istaknuti da je „veliki koeficijent indikator da poduzeće ne koristi novac na najbolji mogući način odnosno novac je potrebno uložiti u poslovanje“ (Gibson, 2011., 226.). Konceptualno postavljen standard za 
vrijednost koeficijenta trenutne likvidnosti je 0,1-0,3 (Tintor, 2009., 532.). Ukoliko poduzeće ima kontinuirano stabilnu vrijednost pokazatelja, njegova prosječna vrijednost može se uzeti kao općenita razina sposobnosti poduzeća da trenutačno podmiri svoje obveze. Sljedeći stupanj ocjene statičke likvidnosti je koeficijent ubrzane likvidnosti kojim se ocjenjuje sposobnost poduzeća da u kratkom roku podmiri sve svoje obveze. Uvažavajući navedeno „brojnik pokazatelja treba uključivati samo onu kratkotrajnu imovinu koju poduzeće može brzo pretvoriti u novac, često tumačeno unutar 90 dana“" (Wahlen et al., 2011., str. 364.). Iako postoji više mogućnosti izračuna pokazatelja radi se o kriteriju kojeg analitičar mora uvažavati jer se u suprotnom gubi njegov smisao. Pokazatelj se može izračunati na način da se u brojnik stavi iznos kratkotrajne imovine umanjen za vrijednost zaliha (Wahlen et al., 2011.; Gibson, 2011.; Orsag, 1997.), međutim nisu uvijek svi preostali oblici kratkotrajne imovine pretvorivi u novac u roku od 90 dana. Da bi se dobio dojam o tome koji dio kratkotrajne imovine uključiti u izračun pokazatelja potrebno je provesti dodatnu analizu parcijalnim pokazateljima aktivnosti kao što su koeficijent obrta potraživanja i izvedeno trajanje naplate potraživanja te analizu strukture i vrste kratkotrajne financijske imovine poduzeća. Poduzeće bi radi minimiziranja rizika trebalo biti sposobno u roku od tri mjeseca podmiriti sve svoje kratkoročne obveze pa je nametnut zahtjev da bi vrijednost pokazatelja trebala biti jedan (Tintor, 2009., 532.). „Visoki pokazatelj ukazuje na značajnu količinu novca i druge brzo unovčive imovine raspoložive za otplatu obveza koje dospijevaju unutar godine dana. Nizak pokazatelj, s druge strane, ukazuje na to da trenutna razina novca i druge brzo unovčive imovine neće biti dovoljna za otplatu kratkoročnih obveza“" (Wahlen et al., 2011., 363.). Najobuhvatniji pokazatelj statičke likvidnosti je koeficijent tekuće likvidnosti s obzirom da se izračunava kao omjer cjelokupne kratkotrajne imovine i kratkoročnih obveza. „Koeficijent tekuće likvidnosti je opći indikator kratkoročnog financijskog položaja poduzeća. Pokazatelj veći od jedan ukazuje na višak kratkotrajne imovine nad kratkoročnim obvezama“ (Holmes et al., 2005, 109). „Promatranjem koeficijenta tekuće likvidnosti pojedinog poduzeća ne postoji jednostavno pravilo koliko bi trebao biti, to ovisi o brojnim čimbenicima od koji su najznačajniji sljedeći:

a) priroda poslovanja poduzeća

b) kvaliteta kratkotrajne imovine

c) neizbježnost kratkoročnih obveza

d) volatilnost potreba za radnim kapitalom“ (Holmes et al., 2005., 109.).

Upravo koeficijent tekuće likvidnosti predstavlja pokazatelj kojem se posvećuje najviše pozornosti s aspekta analize i ocjene likvidnosti. Istaknuto je da bi taj omjer kratkotrajne imovine i kratkoročnih obveza trebao biti minimalno dva (Horrigan, 1968, 285). Vrijednost koeficijenta predstavlja relativni omjer 
kratkotrajne imovine i kratkoročnih obveza dok se apsolutna razlika između navedene dvije stavke naziva neto radni kapital. „Neto radni kapital je popularno mjerilo likvidnosti za koje se može reći da je odraz strukturnih značajki sredstava i obveza ili odraz strukturne ${ }^{1}$ likvidnosti. “(Tintor, 2009., 534.)

Radni kapital je „,mjera sposobnosti poduzeća da komotno obavlja normalno poslovanje bez financijskih napetosti, da širi svoje poslovanje bez potrebe za novim financiranjem i da ispunjava obveze bez neuspjeha" (Graham \& Meredith, 1998., 31.). S aspekta poduzeća da podmiruje svoje obveze važno je promatranje radnog kapitala kao rezerve likvidnosti. Postojanje rezerve likvidnosti „,predstavlja dodatno jamstvo da će se iz veće vrijednosti radnog kapitala generirati gotovina koja će biti dostatna za podmirenje obveza. Tako se odražava sposobnost uspostavljanja dugotrajnih dužničko vjerovničkih odnosa i kontinuiteta poslovne aktivnosti“ (Tintor, 2009., 536.). Veća rezerva likvidnosti označava manji rizik da se neće dovoljna vrijednost kratkotrajne imovine pravovremeno pretvoriti u novac potreban za podmirivanje obveza o njihovom dospijeću. Što je rezerva likvidnosti manja to je rizik ne pretvaranja veći. Osnovno pitanje koje se u tome pogledu postavlja je: što je dovoljna rezerva likvidnosti za pojedino poduzeće? Promatrano tako u prvi plan dolaze do izražaja ranije navedeni čimbenici koje je potrebno promatrati pri ocjeni likvidnosti.

Jedan od jednostavnijih pristupa izračuna brzine cirkulacije kratkotrajne imovine u poduzeću, a samim time i određivanja poželjne razine rezerve likvidnosti, je izračun koeficijenta obrta kratkotrajne imovine te iz njega izvedenog pokazatelja dana vezivanja kratkotrajne imovine. Upravo navedeni dani vezivanja zapravo predstavljaju trajanje operativnog ciklusa poduzeća. Što je operativni ciklus kraći poduzeće si može priuštiti manju rezervu likvidnosti i obrnuto. Potrebno je naglasiti da angažiranje većih vrijednosti radnog kapitala zahtijeva veće izvore financiranja. „Teško je pretpostaviti općevažeće normative likvidnosti pa, sukladno općim uvjetima i sklonostima riskantnim poslovima, likvidnost treba normirati za svako poduzeće². " (Tintor, 2009., 536.) Temeljem određenih normativa svakog poduzeća može se ocijeniti da li ima dostatne iznose rezerve likvidnosti ili je čak prelikvidno (u prevelikoj mjeri preferira sigurnost pred uspješnosti poslovanja).

Tintor (2009.) strukturnu likvidnost još naziva statičkom likvidnosti.

2 Tintor (2009.) navodi da je za izračun potrebnog iznosa radnog kapitala, koji će osigurati neometano podmirivanje obveza i maksimalnu usmjerenost ostvarivanju što većih zarada, potrebno poznavati stopu rizika likvidnosti sredstava koja predstavlja ponderirani zbroj rizika pojedinih sredstava s obzirom da je potrebno uvažavati specifičnosti i značajke pojedinih oblika kratkotrajne imovine. Pored toga, u izračun je potrebno uključiti i rizike povećanja vrijednosti obveza. Formula za izračun poželjnog koeficijenta tekuće likvidnosti na godišnjoj razini je $\mathrm{CR}=(100+\mathrm{r}) /(100-\mathrm{R})$ gdje je $\mathrm{CR}=$ koeficijent tekuće likvidnosti, $\mathrm{r}=$ rizik povećanja vrijednosti obveza, $\mathrm{R}=$ ponderirani zbroj rizika pojedinih sredstava (Tintor, 2009., 537.). Temeljem tako izračunate poželjne vrijednosti koeficijenta tekuće likvidnosti moguće je izračunati potreban iznos neto radnog kapitala koji će osiguravati likvidnost te granicu kratkoročnog zaduživanja koja neće ugrožavati likvidnost poduzeća (detaljnije o tome Tintor, 2009.). 
Dinamička likvidnost poduzeća mjeri se novčanim jazom (engl. cash gap) koji se još naziva ciklus pretvaranja novca (engl. cash conversion cycle). Radi se o pokazateljima koji se izračunavaju na temelju podataka iz bilance i računa dobiti i gubitka. Baza za izračun novčanog jaza su pokazatelji aktivnosti i iz njih izvedeni dani vezivanja. Novčani jaz se izračunava kao omjer broja dana u godini i zbroja koeficijenta obrta potraživanja, koeficijenta obrta zaliha i negativnog koeficijenta obrta obveza prema dobavljačima (formula 1).

Novčani jaz $=\frac{\text { Broj dana u goatn }}{\text { kosficijent obrta potraživanja }+ \text { kosficijent obrta zaliha - kosficijent obrta obveza prema dobavljačima }}$

Dobiveni rezultat predstavlja broj dana između trenutka kada mora podmiriti svoje obveze i trenutka kada će primiti novac na temelju obavljanja svoje djelatnosti. Pitanje je posebno zanimljivo jer se radi o broju dana za koje poduzeće treba angažirati dodatna sredstva da bi premostilo jaz odnosno mora se dodatno zadužiti. Dodatno zaduživanje predstavlja skupe troškove financiranja koji imaju izravan utjecaj na smanjenje profitabilnosti. Iz navedenog je jasno zašto su napori menadžmenta usmjereni na smanjivanje novčanog jaza. Poduzeća mogu imati negativni novčani jaz što označava situaciju u kojoj primaju novac prije trenutka kada moraju podmiriti svoje obveze pa se može zaključiti da u toj situaciji raspolažu s određenim novčanim suficitom. Utjecaj novčanog jaza na profitabilnost poduzeća moguće je izračunati na način da se prihodi od prodaje umanje za kontribuciju pri čemu se dobivaju troškovi proizvodnje koji se dijeljenjem s brojem dana u godini svode na dnevne potrebe za novčanim sredstvima, a množenjem dnevnih potreba s brojem dana novčanog jaza dobivaju se ukupno potrebna novčana sredstva financiranja za koje je potrebno izračunati troškove financiranja primjenom tržišnih kamatnih stopa (Tintor, 2009., 882.).

Pokazateljima statičke zaduženosti ocjenjuje se struktura izvora financiranja. Primjenom koeficijenta zaduženosti, koeficijenta vlastitog financiranja ili koeficijenta financiranja dolazi se do istih zaključaka promatrano s različitih aspekata. Koeficijentom zaduženosti i koeficijentom vlastitog financiranja ocjenjuje su udio tuđih odnosno vlastitih izvora financiranja u ukupnoj imovini poduzeća. Odabirom tuđih izvora financiranja imovine, poduzeća se izlažu financijskom riziku³ . Taj rizik prije svega uključuje nemogućnost poduzeća da vrati posuđene

3 „Financijski rizik vezan je za strukturu izvora financiranja te ovisi o pitanju financiranja poslovnih aktivnosti, u slučaju kada su poslovne aktivnosti u potpunosti financirane vlastitim izvorima, nema financijskog rizika“ (Solomon \& Muntean, 2012., 60.). Odabirom određene strukture izvora financiranja poduzeće se izlaže financijskom riziku. „Financijski rizik karakterizira varijabilnost neto dobiti uslijed strukture izvora financiranja poduzeća. Ne postoji pred- 
izvore financiranja o roku dospijeća. „Općenito, veći dug znači viši financijski rizik i prema tome indikator je slabije solventnosti“" (Robinson et al., 2009., 289.). „Pokazatelj zaduženosti trebao bi se uspoređivati s tim pokazateljem konkurenata $\mathrm{i}$ industrijskim prosjekom. Industrije koje imaju stabilne zarade mogu podnijeti više obveza od industrija s cikličnim zaradama" (Gibson, 2011., 260.).

Koeficijentom financiranja ocjenjuje se omjer tuđih i vlastitih izvora. Koeficijent financiranja u literaturi se još naziva mjerom financijske poluge (Solomon \& Muntean, 2012., 60.; Palepu \& Healy, 2013., 202.; Petersen \& Plenborg, 2012., 117.). Iako se radi o pojmu koji nije izravno povezan sa sigurnošću poslovanja u konačnici je poboljšava. Pozitivno djelovanje financijske poluge označava situaciju u kojoj poduzeće uslijed korištenja tuđih izvora financiranja ostvaruje veće povrate nego što bi ih ostvarivalo da poslovanje financira vlastitim izvorima odnosno time što koristi tuđe izvore financiranja stvara veće zarade za vlasnike poduzeća. „Ekonomski efekt posuđivanja je pozitivan dok god je rentabilnost imovine veća od troška posuđivanja. Poduzeća koja nemaju adekvatne povrate za plaćanje troška kamata, zaduživanjem smanjuju rentabilnost vlastitog kapitala“ (Palepu et al., 2007., 202.).

Najznačajniji pokazatelj dinamičke zaduženosti je pokriće troškova kamata. „Jedan od uobičajenih načina izračuna pokrića troškova kamata uključuje utvrđivanje odnosa između zarada prije kamata i poreza (engl. earnings before interest and taxes -EBIT) i troškova kamata“ (Wahlen et al., 2011., 372.). „Veće pokriće troškova kamata ukazuje na snažniju solventnost, pružajući veću sigurnost da poduzeće može podmirivati svoje dugove ( $\mathrm{tj}$. obveze za kredite, obveznice, komercijalne zapise) iz zarada iz poslovnih aktivnosti“ (Robinson et al., 2009., 290.). Nema ograničenja na visinu navedenog pokazatelja, ali je potrebno u analizu uključiti i strukturu izvora financiranja. Uobičajeno će poduzeća s izrazito niskim udjelom tuđih izvora financiranja imati izrazito povoljnu vrijednost pokazatelja što u tome slučaju nema značajnu iterpretatvnu vrijednost. Značajnojst pokazatelja dolazi do izražaja što se poduzeće u većoj mjeri oslanja na tuđe izvore financiranja. Granična vrijednost pokrića troškova kamata je jedan. U tome slučaju može se zaključiti da poduzeće sve ostvarene zarade prepušta vlasnicima tuđih izvora financiranja. Što je vrijednost pokazatelja veća, veći dio zarada ostaje vlasnicima poduzeća u odnosu na vlasnike tuđih izvora financiranja. Nepovoljna je situacija u kojoj je vrijednost pokazatelja manja od jedan što znači da poduzeće ne ostvaruje dovoljne zarade za podmirivanje troškova tuđih izvora financiranja te se dio troškova financiranja podmiruje na teret vlastitih izvora financiranja što dugoročno vodi u insolventnost.

ložak čimbenika financiranja, svaka poslovna djelatnost poduzeća određuje vlastite značajne varijacije od slučaja do slučaja. Optimalna struktura izvora financiranja maksimizirat će vrijednost poduzeća balansiranjem stupnja rizika i očekivane stope povrata“" (Solomon \& Muntean, 2012., 58.). 
Pored navedenih pojmova za ocjenu sigurnosti poslovanja koristi se i pojam financijske stabilnosti. Općenito promatrano financijska stabilnost ocjenjuje primjenu zlatnih pravila financiranja prema kojima se dugotrajna imovina mora financirati iz dugoročnih izvora, kratkotrajna imovina iz kratkoročnih izvora te dio kratkotrajne imovine (neto radni kapital) iz dugoročnih izvora. Prema tome, financijska stabilnost zapravo označava adekvatno strukturiranje imovine s izvorima imovine. Mjere financijske stabilnosti su koeficijent financijske stabilnosti, stupanj pokrića I i stupanj pokrića II. Koeficijentom financijske stabilnosti ocjenjuje se koliki se udio dugoročnih izvora financiranja koristi za financiranje dugotrajne imovine i usporedno s tim koliki je udio tih dugoročnih izvora preostao za financiranje kratkotrajne imovine iz čega proizlazi da vrijednost pokazatelja mora biti manja od jedan s obzirom da se dio kratkotrajne imovine mora financirati iz dugoročnih izvora. S druge strane, stupnjem pokrića II ista situacija se promatra s drugog aspekta odnosno sa strane dugotrajne imovine gdje se ocjenjuje da li je cjelokupna dugotrajna imovina pokrivena dugoročnim izvorima financiranja dok se stupnjem pokrića I ocjenjuje koliki je dio dugotrajne imovine financiran vlastitim izvorima financiranja. Poželjno je da je stupanj pokrića I što bliži vrijednosti jedan dok je nužan uvjet da stupanj pokrića veći od jedan što je u korelaciji s nužnom vrijednosti koeficijenta financijske stabilnosti. Zbog aspekta s kojega se ocjenjuje financijska stabilnost, prema pojedinima autorima, koeficijent financijske stabilnosti moguće je klasificirati kao pokazatelj likvidnosti, a stupnjeve pokrića kao pokazatelje zaduženosti (Žager, K. et al., 2017., 46-49.).

\section{OCJENA LIKVIDNOSTI SREDNJE VELIKIH I VELIKIH PODUZEĆA REALNOG SEKTORA U REPUBLICI HRVATSKOJ}

Upravljanje likvidnosti predstavlja uvijek aktualno pitanje i svakodnevnu aktivnost menadžmenta svakog poduzeća neovisno o njegovoj veličini, djelatnosti ili području djelovanja. Posebni izazovi stavljeni su pred poduzeća zemalja u razvoju kao što je Republika Hrvatska, a posebice zadnjih godina nepovoljnog makroekonomskog okruženja. Od samog upravljanja likvidnosti u prvi plan dolazi i pitanje solventnosti kao osnovne opstanka poduzeća na tržištu.

U radu je provedeno istraživanje stanja likvidnosti i solventnosti srednje velikih i velikih poduzeća u Republici Hrvatskoj za razdoblje od 2005. do 2015. godine. Za potrebe istraživanja oblikovan je slučajni uzorak srednje velikih i velikih poduzeća uz uvjet da su kontinuirano poslovali kroz cjelokupno promatrano razdoblje. Analizirana poduzeća su podijeljena na područja djelatnosti u skladu s poslovnim strukturnim statistikama hrvatskog Državnog zavoda za statistiku i statističkog ureda Europske unije (engl. statistical office of the European Union -Eurostat). Skupine djelatnosti prema kojima su poduzeća klasificirana su 
Industriju, Građevinarstvo, Trgovinu i Nefinancijske usluge, a uključuju sva relevantna područja prema Nacionalnoj klasifikaciji djelatnosti (Nacionalna klasifikacija djelatnosti; Narodne novine br. 58/2007.).

Prema podacima dostupnima na stranicama Registra poslovnih subjekata Hrvatske gospodarske komore u Republici Hrvatskoj u 2015. godini je bilo aktivno ukupno 107.583 poduzeća koja su pripremila i predala godišnje financijske izvještaje od čega su 1.094 srednje velika i 320 velikih poduzeća.

Tablica 2: Usporedba broja i strukture aktivnih srednje velikih i velikih te poduzeća izabranih u uzorak u Republici Hrvatskoj u 2015. godini

\begin{tabular}{|c|c|c|c|}
\hline \multirow{2}{*}{$\begin{array}{c}\text { SKUPINA DJELAT- } \\
\text { NOSTI }\end{array}$} & \multicolumn{3}{|c|}{ BROJ PODUZEĆA } \\
\cline { 2 - 4 } & UZORAK & UKUPNO & UDIO \\
\hline Industrija & 68 & 605 & $11,24 \%$ \\
\hline Građevinarstvo & 17 & 129 & $13,18 \%$ \\
\hline Trgovina & 44 & 369 & $11,92 \%$ \\
\hline Nefinancijske usluge & 25 & 311 & $8,04 \%$ \\
\hline Ostalo & 4 & $/$ & $/$ \\
\hline UKUPNO & 158 & 1.414 & $11,17 \%$ \\
\hline
\end{tabular}

Izvor: Registar poslovnih subjekata Hrvatske gospodarske komore, dostupno na: http://www1.biznet.hr/HgkWeb/do/fullSearchPost (datum pristupanja: 19.07.2017.); Registar godišnjih financijskih izvještaja. Financijska agencija. Podaci dobiveni putem e-maila.

Za potrebe istraživanja, uvažavajući dane parametre po pitanju djelatnosti i veličine, oblikovan je slučajni uzorak od 158 poduzeća (Tablica 2). Relevantni podaci iz godišnjih financijskih izvještaja za jedanaestogodišnje razdoblje (2005-2015.) prikupljeni su iz Registra godišnjih financijskih izvještaja Financijske agencije. Uzorak obuhvaća 11,17 \% populacije, a uključuje 119 srednje velikih i 39 velikih poduzeća podjednako raspoređenih prema skupinama djelatnosti. S obzirom na to dobiveni rezultati mogu se smatrati reprezentativnima za usvajanje zaključaka o osnovnom skupu.

Analiza likvidnosti i solventnosti poduzeća u Republici Hrvatskoj provedena je temeljem statičkih i dinamičkih pojedinačnih financijskih pokazatelja (Tablica 3). Formule za izračun pokazatelja prilagođene su dostupnim podacima. Primjerice, prema Pravilniku o strukturi i sadržaju godišnjih financijskih izvještaja (Narodne novine br. 95/2016.) objavljuje se informacija o financijskim rashodima, koji pored rashoda od kamata uključuju i ostale financijske rashode kao što su primjerice negativne tečajne razlike. Pored toga provedena je analiza ostvarenih prihoda i strukture kratkotrajne imovine kako bi se sagledala uloga strukture imovine u ocjeni sigurnosti poslovanja. 
Tablica 2. Formule za izračun financijskih pokazatelja korištenih u analizi

\begin{tabular}{|c|c|}
\hline FINANCIJSKI POKAZATELJ & FORMULA ZA IZRAČUN POKAZATE- \\
LJA
\end{tabular}

Izvor: Žager K. et al., 2009; Wahlen et al., 2011; Gibson, 2011

Prema objavljenim podacima Državnog zavoda za statistiku poduzeća uključena u strukturne poslovne statistike, a koja su predala godišnje financijske izvještaje za 2015. godinu ostvarila su ukupno 569,2 milijarde kuna prihoda od prodaje ${ }^{4}$ (Tablica 3). Poduzeća obuhvaćena analizom ukupno su ostvarila 52,9 milijarde kuna prometa što čini oko $9 \%$ ukupnog prometa svih aktivnih poduzeća (mikro, malih, srednje velikih i velikih)

4 Promet (EU šifra 12110) obuhvaća obračunate prihode od prodaje proizvoda, roba i usluga trećim stranama, bez odbitnog poreza na dodanu vrijednost. Isključeni su financijski, ostali i izvanredni prihodi. Izvor: Državni zavod za statistiku Republike Hrvatske, Strukturne-poslovne statistike. 
Tablica 3: Prihodi od prodaje aktivnih poduzeća i ukupni prihodi poduzeća izabranih u uzorak u Republici Hrvatskoj u 2015. godini razvrstana prema skupini djelatnosti (izno-

si u tisućama kuna)

\begin{tabular}{|c|c|c|c|}
\hline $\begin{array}{c}\text { SKUPINA DJE- } \\
\text { LATNOSTI }\end{array}$ & $\begin{array}{c}\text { PRIHODI OD PRO- } \\
\text { DAJE UKUPNOG } \\
\text { BROJA PODUZE- } \\
\text { ĆA }\end{array}$ & $\begin{array}{c}\text { UKUPNI PRIHODI } \\
\text { PODUZEĆA IZ } \\
\text { UZORKA }\end{array}$ & UDIO \\
\hline Industrija & 196.801 .728 & 23.280 .487 & $11,83 \%$ \\
\hline Građevinarstvo & 41.326 .427 & 4.088 .359 & $9,89 \%$ \\
\hline Trgovina & 224.865 .151 & 21.597 .317 & $9,60 \%$ \\
\hline $\begin{array}{c}\text { Nefinancijske us- } \\
\text { luge }\end{array}$ & 128.365 .369 & 3.903 .075 & $3,04 \%$ \\
\hline UKUPNO & 591.358 .675 & 52.869 .237 & $8,94 \%$ \\
\hline
\end{tabular}

Izvor: Državni zavod za statistiku Republike Hrvatske, Strukturne-poslovne statistike poduzeća, dostupno na: http://www.dzs.hr/Hrv/DBHomepages/Strukturne\%20 poslovne \%20statistike/Strukturne\%20poslovne\%20statistike.htm (datum pristupanja:

19.07.2017.); Registar godišnjih financijskih izvještaja. Financijska agencija. Podaci dobiveni putem e-maila.

Prema prosječnoj vrijednosti koeficijenta tekuće likvidnosti srednje velika i velika poduzeća u Republici Hrvatskoj nisu imala problema s likvidnosti. Prosječna vrijednost pokazatelja je kroz jedanaestogodišnje razdoblje veća od dva, a najpovoljnije vrijednosti dobivene su upravo za recesijske godine (Tablica 4). To se može objasniti kao situacija u kojoj uslijed nepovoljnih uvjeta poduzeća nastoje poslovati manje rizično. Temeljem koeficijenta ubrzane likvidnosti koji je izračunat kao omjer kratkotrajne imovine umanjene za vrijednost zaliha i kratkoročnih obveza može se zaključiti da poduzeća u prosjeku imaju više brzo unovčive imovine o kratkoročnih obveza s obzirom da je prosječna vrijednost pokazatelja veća od jedan. S obzirom da je trajanje naplate potraživanja u prosjeku manje od 90 dana opravdano je uključiti potraživanja u izračun koeficijenta ubrzane likvidnosti. Razlike između prosječnih vrijednosti koeficijenta tekuće likvidnosti i koeficijenta ubrzane likvidnosti predstavljaju 'teret' zaliha analiziranih poduzeća što se može zaključiti temeljem visokog broja dana vezivanja zaliha kroz sva analizirana razdoblja. Srednje velika i velika poduzeća u Republici Hrvatskoj svoju imovinu manjim dijelom financiraju iz vlastitih izvora financiranja što se može vidjeti iz izračunatog koeficijenta vlastitog financiranja. U skladu s tim moguće je izvesti zaključak da se u prosjeku više od $60 \%$ imovine financirana tuđim izvorima financiranja (koeficijent zaduženosti = koeficijent vlastitog financiranja - 1). Moguće je zaključiti da prosječne vrijednosti statičkih pokazatelja likvidnosti i zaduženosti prikazuju izrazito stabilno poslovanje tijekom jedanaestogodišnjeg razdoblja. 
Tablica 4: Prosječne vrijednosti izračunatih financijskih pokazatelja analiziranih srednje velikih i velikih poduzeća u Republici Hrvatskoj za razdoblje od 2005. do 2015. godine

\begin{tabular}{|c|c|c|c|c|c|c|c|c|}
\hline GODINA & KTL & KUL & KVF & PTK & CCC & TNP & DVZ & DNO \\
\hline 2005 & 2,066 & 1,573 &, 367 & 24,499 & 202 & 70 & 155 & 30 \\
\hline 2006 & 2,031 & 1,534 &, 369 & 62,684 & 201 & 70 & 151 & 28 \\
\hline 2007 & 2,154 & 1,554 &, 370 & 61,075 & 235 & 74 & 168 & 28 \\
\hline 2008 & 2,270 & 1,716 &, 382 & 85,335 & 97 & 59 & 101 & 64 \\
\hline 2009 & 2,465 & 1,812 &, 390 & 11,115 & 127 & 64 & 134 & 69 \\
\hline 2010 & 2,203 & 1,658 &, 383 & 39,386 & 106 & 62 & 108 & 62 \\
\hline 2011 & 2,099 & 1,556 &, 377 & 9,416 & 96 & 58 & 102 & 62 \\
\hline 2012 & 2,019 & 1,450 &, 359 & 20,945 & 104 & 57 & 121 & 71 \\
\hline 2013 & 2,232 & 1,661 &, 355 & 45,935 & 112 & 55 & 117 & 58 \\
\hline 2014 & 2,236 & 1,667 &, 373 & 17,055 & 133 & 52 & 142 & 59 \\
\hline 2015 & 2,436 & 1,797 &, 397 & 691,140 & 108 & 50 & 115 & 54 \\
\hline
\end{tabular}

KTL: koeficijent tekuće likvidnosti

KUL: koeficijent ubrzane likvidnosti

KVF: koeficijent vlastitog financiranja

PTK: pokriće troškova kamata

CCC: novčani jaz

TNP: trajanje naplate potraživanja od kupaca

DVZ: dani vezivanja zaliha

DPO: dani plaćanja obveza prema dobavljačima

Izvor: izračun autora

Za razliku od statičkih, kod dinamičkih pokazatelja likvidnosti i zaduženosti moguće je primijetiti određene promjene kroz razdoblje od 2005. do 2015. godine. Rezultati pokrića troškova kamata prikazuju značajnu volatilnost što može biti rezultat negativnih tečajnih razlika koje su uključene u financijske rashode. $\mathrm{S}$ druge strane kod prosječnih vrijednosti pokazatelja dinamičke likvidnosti moguće je primijetiti pozitivan tren smanjivanja novčanog jaza. Tijekom godina koje su u hrvatskom gospodarstvu obilježene kao godine ekspanzije srednje velika i velika poduzeća imala su najveći novčani jaz od preko 200 dana. Tijekom recesijskih godina prosječni novčani jaz je čak dvostruko smanjen te je 2011. godine izračunat najmanji prosječni novčani jaz od 96 dana.

Analizom dobivenih rezultata moguće je primijetiti da je novčani jaz od 235 dana iz 2007. godine smanjen na 97 dana u 2008. godini. Radi se o izrazito značajnom povoljnom pomaku za 138 dana, a pitanje koje se postavlja je što je do toga dovelo. Analizom parcijalnih pokazatelja novčanog jaza primjećuje se trostruki efekt 
utjecaja na novčani jaz, a to je smanjenje trajanja naplate potraživanja od kupaca sa 74 na 59 dana, smanjenje dana vezivanja zaliha sa 168 na 101 dan te povećanje dana plaćanja obveza prema dobavljačima s 28 na 64 dana u 2008. u odnosu na 2007. godinu

Tablica 5: Prosječne vrijednosti koeficijenta tekuće likvidnosti i novčanog jaza analiziranih poduzeća u Republici Hrvatskoj prema skupinama djelatnosti za razdoblje od 2005. do 2015. godine

\begin{tabular}{|c|c|c|c|c|c|c|c|c|}
\hline \multirow{2}{*}{ Godina } & \multicolumn{9}{|c|}{ Djelatnost } \\
\cline { 2 - 10 } & \multicolumn{2}{|c|}{ Industrija } & \multicolumn{2}{c|}{ Građevinarstvo } & \multicolumn{2}{|c|}{ Trgovina } & \multicolumn{2}{c|}{$\begin{array}{c}\text { Nefinancijske } \\
\text { usluge }\end{array}$} \\
\cline { 2 - 10 } & KTL & CCC & KTL & CCC & KTL & CCC & KTL & CCC \\
\hline 2005 & 2,18 & 166 & 1,90 & 388 & 1,95 & 255 & 1,89 & 83 \\
\hline 2006 & 2,32 & 157 & 1,58 & 417 & 1,89 & 255 & 1,63 & 85 \\
\hline 2007 & 2,25 & 172 & 1,82 & 554 & 2,27 & 315 & 1,81 & 65 \\
\hline 2008 & 2,18 & 113 & 1,68 & 215 & 2,56 & 55 & 2,13 & 23 \\
\hline 2009 & 2,56 & 157 & 1,52 & 126 & 3,13 & 118 & 1,51 & 15 \\
\hline 2010 & 2,55 & 141 & 1,59 & 134 & 2,03 & 67 & 1,88 & 16 \\
\hline 2011 & 2,61 & 122 & 1,62 & 129 & 1,79 & 63 & 1,55 & 19 \\
\hline 2012 & 2,35 & 118 & 1,46 & 135 & 1,82 & 68 & 1,76 & 98 \\
\hline 2013 & 2,61 & 131 & 1,56 & 127 & 1,80 & 61 & 2,37 & 142 \\
\hline 2014 & 2,51 & 135 & 1,51 & 115 & 1,85 & 60 & 2,45 & 292 \\
\hline 2015 & 2,45 & 138 & 1,76 & 109 & 2,26 & 63 & 2,75 & 89 \\
\hline
\end{tabular}

KTL: koeficijent tekuće likvidnosti

CCC: novčani jaz

Izvor: izračun autora

S obzirom da je tijekom navedenog razdoblja došlo do povećanja i prosječne i ukupne vrijednosti kratkotrajne imovine i kratkoročnih obveza analiziranih poduzeća moguće je zaključiti da je navedeni trend kretanja novčanog jaza posljedica značajnijeg povećanja ukupnih prihoda i vezano uz to rashoda poslovanja (Tablica 4). Sveukupno promatrano, unatoč povoljnom trendu kroz analizirana razdoblja, novčani jaz srednje velikih i velikih poduzeća u Republici Hrvatskoj je previsok. Iako su poduzeća u određenoj mjeri smanjila prosječno trajanje naplate potraživanja na manje od dva mjeseca te prolongirala plaćanje obveza s mjesec na gotovo dva mjeseca, značajno opterećenje poduzećima predstavljaju zalihe koje se zadržavaju na skladištu u prosjeku gotovo četiri mjeseca u 2015. godini. Prosječno trajanje operativnog ciklusa analiziranih poduzeća u 2015. godini bilo je 125 dana (prosječna vrijednost koeficijenta obrta kratkotrajne imovine 2,928) 
što je relativno dugo razdoblje, a u najvećoj mjeri vezano je za dugo razdoblje vezivanja zaliha.

Jedan od čimbenika koji je relevantan za ocjenu likvidnosti je i djelatnost poduzeća. U tome kontekstu očekivano je da će se pokazatelji likvidnosti razlikovati kod proizvođačkih poduzeća u odnosu na poduzeća koja se primarno bave pružanjem usluga ili trgovinom. Prema dobivenim rezultatima uvažavajući djelatnost poduzeća (Tablica 5) može se primijetiti da postoje razlike u prosječnim vrijednostima izračunatih koeficijenata tekuće likvidnosti i pokazatelja novčanog jaza. Najbolje prosječne vrijednosti koeficijenta tekuće likvidnosti imaju poduzeća u sektoru industrije dok je ta vrijednost najnepovoljnija u sektoru građevinarstva. $\mathrm{S}$ druge strane poduzeća iz sektora industrije imaju najstabilniji novčani jaz kroz promatranih 11 godina iako njegova vrijednost nije najpovoljnija. Najznačajnije poboljšanje novčanog jaza imaju poduzeća u sektoru trgovine. Poduzeća koja se bave pružanjem nefinancijskih usluga pokazuju najznačajniju volatilnost dobivenih rezultata.

Tablica 6: Prosječne vrijednosti koeficijenta tekuće likvidnosti i novčanog jaza analiziranih poduzeća u Republici Hrvatskoj prema veličini za razdoblje od 2005. do 2015. godine

\begin{tabular}{|c|c|c|c|c|}
\hline \multirow{2}{*}{ Godina } & \multicolumn{4}{|c|}{ Veličina poduzeća } \\
\cline { 2 - 5 } & Srednje-velika poduzeća & \multicolumn{2}{c|}{ Velika poduzeća } \\
\cline { 2 - 5 } & KTL & NJ & KTL & NJ \\
\hline 2005 & 2,06 & 218 & 2,08 & 164 \\
\hline 2006 & 2,15 & 222 & 1,68 & 152 \\
\hline 2007 & 2,32 & 271 & 1,66 & 152 \\
\hline 2008 & 2,48 & 103 & 1,61 & 83 \\
\hline 2009 & 2,79 & 125 & 1,47 & 131 \\
\hline 2010 & 2,41 & 115 & 1,59 & 81 \\
\hline 2011 & 2,24 & 106 & 1,66 & 65 \\
\hline 2012 & 2,13 & 120 & 1,67 & 56 \\
\hline 2013 & 2,30 & 130 & 2,03 & 61 \\
\hline 2014 & 2,26 & 152 & 2,17 & 79 \\
\hline 2015 & 2,55 & 122 & 2,08 & 72 \\
\hline
\end{tabular}

KTL: koeficijent tekuće likvidnosti

CCC: novčani jaz

Izvor: izračun autora 
Uz djelatnost poduzeća, važan čimbenik kojeg je potrebno uvažavati pri ocjeni likvidnosti je i veličina poduzeća. Prema rezultatima iz tablice 6 srednje velika poduzeća imaju povoljniju prosječnu vrijednost koeficijenta tekuće likvidnosti od velikih poduzeća. U svim analiziranim godinama prosječna vrijednost koeficijenta tekuće likvidnosti veća je od dva. S druge strane srednje velika poduzeća lošije upravljaju likvidnosti s obzirom na prosječan broj dana novčanog jaza. U zadnjoj analiziranoj godini prosječni broj dana novčanog jaza kod srednje velikih poduzeća za 50 dana je veći od prosječnog broja dana novčanog jaza u velikim poduzećima. Iako obje skupine poduzeća imaju povoljno kretanje kroz analizirane godine, srednje velika poduzeća još uvijek imaju jaz od četiri mjeseca od dana kada moraju platiti obveze do dana kada će primiti novac od svojih kupaca.

Tablica 7: Prosječne i ukupne vrijednosti prihoda, kratkotrajne imovine i kratkoročnih obveza analiziranih srednje velikih i velikih poduzeća u Republici Hrvatskoj za razdoblje od 2005. do 2015. godine (iznosi u tisućama kuna)

\begin{tabular}{|c|c|c|c|c|c|c|}
\hline \multirow[t]{2}{*}{ GODINA } & \multicolumn{2}{|c|}{$\begin{array}{l}\text { UKUPNI } \\
\text { PRIHODI }\end{array}$} & \multicolumn{2}{|c|}{$\begin{array}{l}\text { KRATKOTRAJNA } \\
\text { IMOVINA }\end{array}$} & \multicolumn{2}{|c|}{$\begin{array}{c}\text { KRATKOROČNE } \\
\text { OBVEZE }\end{array}$} \\
\hline & AVG & SUM & AVG & SUM & AVG & SUM \\
\hline 2005 & 208.765 & 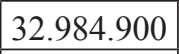 & 79.247 & 12.521 .049 & 62.958 & 9.947 .311 \\
\hline 2006 & 234.071 & 36.983 .210 & 92.462 & 14.609 .003 & 81.673 & 12.904 .267 \\
\hline 2007 & 259.456 & 40.993 .983 & 107.035 & 16.911 .603 & 95.243 & 15.048 .444 \\
\hline 2008 & 306.264 & 48.389 .787 & 127.917 & 20.210 .855 & 125.031 & 19.754 .953 \\
\hline 2009 & 285.956 & 45.180 .995 & 124.708 & 19.703 .910 & 122.508 & 19.356 .233 \\
\hline 2010 & 284.588 & 44.964 .947 & 118.673 & 18.750 .263 & 117.153 & 18.510 .212 \\
\hline 2011 & 296.960 & \begin{tabular}{|l|}
46.919 .720 \\
\end{tabular} & 124.220 & 19.626 .734 & 129.048 & 20.389 .578 \\
\hline 2012 & 302.693 & 47.825 .441 & 125.172 & 19.777 .145 & 141.678 & 22.385 .145 \\
\hline 2013 & 335.507 & 53.010 .114 & 137.426 & 21.713 .376 & 157.593 & 24.899 .625 \\
\hline 2014 & 338.683 & 53.511 .940 & 142.200 & 22.467 .555 & 143.828 & 22.724 .900 \\
\hline 2015 & 338.481 & 53.480 .063 & 139.980 & 22.116 .873 & 141.172 & 22.305 .240 \\
\hline
\end{tabular}

AVG: prosječna vrijednost

SUM: ukupna vrijednost

Izvor: izračun autora

Detaljnijom analizom strukture imovine srednje velikih i velikih poduzeća moguće je primijetiti smanjenje udjela potraživanja od kupaca u kratkotrajnoj imovini s gotovo $40 \%$ početkom analiziranog razdoblja na manje od $25 \%$ u 2015 . godini. 
Tablica 8: Odabrani indikatori poslovanja analiziranih poduzeća u Republici Hrvatskoj za razdoblje od 2005. do 2015. godine

\begin{tabular}{|c|c|c|c|}
\hline GODINA & $\begin{array}{c}\text { UDIO } \\
\text { POTRAŽIVANJA } \\
\text { OD KUPACA U } \\
\text { KRATKOTRAJNOJ } \\
\text { IMOVINI }\end{array}$ & $\begin{array}{c}\text { KRATKOTRAJNOJ } \\
\text { IMOVINI }\end{array}$ & $\begin{array}{c}\text { UDIO } \\
\text { POTRAŽIVANJA } \\
\text { OD KUPACA } \\
\text { U UKUPNIM } \\
\text { PRIHODIMA }\end{array}$ \\
\hline 2005 & 0,37926 & 0,30772 & 0,14397 \\
\hline 2006 & 0,41051 & 0,29662 & 0,16216 \\
\hline 2007 & 0,39611 & 0,30391 & 0,16341 \\
\hline 2008 & 0,31007 & 0,32107 & 0,12951 \\
\hline 2009 & 0,29384 & 0,29729 & 0,12815 \\
\hline 2010 & 0,28679 & 0,30816 & 0,11959 \\
\hline 2011 & 0,27208 & 0,30380 & 0,11381 \\
\hline 2012 & 0,26704 & 0,30899 & 0,11043 \\
\hline 2013 & 0,24100 & 0,27688 & 0,09871 \\
\hline 2014 & 0,24463 & 0,26149 & 0,10271 \\
\hline 2015 & 0,24479 & 0,25668 & 0,10123 \\
\hline
\end{tabular}

Izvor: izračun autora

Da smanjenje potraživanja od kupaca nije rezultat smanjene aktivnosti i obujma poslovanja analiziranih poduzeća vidljivo je kroz povećanje prihoda od 2005. do 2015. godine (Tablica 7) što je rezultiralo smanjenjem udjela potraživanja od kupaca u sumi ukupnih prihoda s $14,40 \%$ u 2005. na 10,12\% u 2015. godini (Tablica 8). Iako se nedvojbeno radi o povoljnom trendu potrebno je detaljno analizirati politike poduzeća upravljanja potraživanjima (otpis, instrumenti osiguranja plaćanja, faktoring). 
Tablica 9: Povezanost statičkih i dinamičkih pokazatelja likvidnosti i zaduženosti

\begin{tabular}{|c|c|c|c|c|c|}
\hline & & CCC & KTL & KVF & PTK \\
\hline \multirow{2}{*}{ CCC } & Pearson Correlation & 1 & .028 & -.029 & -.008 \\
\cline { 2 - 6 } & Sig. (2-tailed) & & .273 & .270 & .770 \\
\hline \multirow{2}{*}{ KTL } & Pearson Correlation & .028 & 1 & $.416^{* *}$ & $.063^{* *}$ \\
\cline { 2 - 6 } & Sig. (2-tailed) & .273 & & .000 & .009 \\
\hline \multirow{2}{*}{ KVF } & Pearson Correlation & -.029 & $.416^{* *}$ & 1 & $.057^{*}$ \\
\cline { 2 - 6 } & Sig. (2-tailed) & .270 & .000 & & .017 \\
\hline \multirow{2}{*}{ PTK } & Pearson Correlation & -.008 & $.063^{* *}$ & $.057^{*}$ & 1 \\
\cline { 2 - 6 } & Sig. (2-tailed) & .770 & .009 & .017 & \\
\hline & $* *$ Correlation is significant at the 0.01 level (2-tailed). \\
& $*$. Correlation is significant at the 0.05 level (2-tailed).
\end{tabular}

$\mathrm{CCC}$ : novčani jaz

KTL: koeficijent tekuće likvidnosti

KVF: koeficijent vlastitog financiranja

PTK: pokriće troškova kamata

Izvor: izračun autora

Prema dobivenim rezultatima provedene analize korelacije moguće je zaključiti da ne postoji statistički značajna povezanost novčanog jaza s preostalim korištenim pokazateljima likvidnosti i zaduženosti (Tablica 9). S druge strane postoji umjerena pozitivna statistički značajna korelacija koeficijenta tekuće likvidnosti s koeficijentom vlastitog financiranja i slaba pozitivna povezanost s pokrićem troškova kamata. Dobiveni rezultati opravdavaju potrebu provedbe analize različitim pokazateljima i instrumentima kako bi se provedbom analize dobio obuhvatan zaključak o likvidnosti poslovanja poduzeća. 


\section{ZAKLJUČAK}

Pitanje likvidnosti i solventnosti uvijek je značajno za poslovanje svih poduzeća. Rad obuhvaća sistematizaciju odrednica koje imaju značaj za ocjenu likvidnosti poduzeća. Dan je pregled alata koji se uobičajeno primjenjuju za ocjenu likvidnosti poduzeća. U radu je provedena analiza likvidnosti srednje velikih i velikih poduzeća realnog sektora u Republici Hrvatskoj. Tijekom cijelog analiziranog razdoblja zalihe imaju udio od oko $30 \%$ u kratkotrajnoj imovini analiziranih poduzeća. Uz prethodno navedeno da se zalihe predugo zadržavaju na skladištu i činjenicu da zauzimaju značajni udio kratkotrajne imovine može se zaključiti da analizirana poduzeća trebaju imati veću vrijednost neto radnog kapitala kako bi likvidnost zadržala na zadovoljavajućoj razini što je i vidljivo kroz koeficijent tekuće likvidnosti koji je u prosjeku veći od dva. Bolje upravljanje zalihama omogućilo bi poduzećima smanjenje rezerve likvidnosti čime bi ostvarili značajne uštede na ime rashoda od kamata što bi se izravno reflektiralo na poboljšanje profitabilnosti i smanjenje zaduženosti odnosno poboljšanje solventnosti poslovanja. Pored rezultata o novčanom jazu taj zaključak potkrjepljuje i prosječna vrijednost koeficijenta ubrzane likvidnosti koja se uvelike razlikuje od prosječne vrijednosti koeficijenta tekuće likvidnosti uslijed značajnog udjela zaliha u imovini analiziranih poduzeća. U idućim fazama istraživanja trebala bi se ispitati statistička značajnost dobivenih razlika u prosječnim vrijednostima pokazatelja u odnosu na djelatnosti i veličinu poduzeća. Buduća istraživanja mogu biti usmjerena detaljnijoj analizi strukture imovine prema djelatnostima kako bi se utvrdili glavni razlozi dobivenih rezultata istraživanja. Ograničenje istraživanja je nemogućnost dobivanja informacija o starosnoj strukturi zaliha poduzeća čime bi se značajno povećala relevantnost iznesenih zaključaka. Pored toga, ograničenje je činjenica da je istraživanje usmjereno samo na srednje velika i velika poduzeća, tj. ne uključuje mikro i mala poduzeća koja čine preko 90 \% subjekta u Republici Hrvatskoj. Međutim, analizirana srednje velika i velika poduzeća uvjerljivo ostvaruju najveći udio u ukupno ostvarenim prihodima što znači da njihovo poslovanje ima najznačajniji utjecaj na hrvatsko gospodarstvo. 


\section{LITERATURA}

1. Anić, V., \& Goldstein, I., Pretraživanje rječničke baze. (Novi Liber, Producer), dostupno na: Hrvatski jezični portal: http://hjp.novi-liber.hr/index. php?show=search (datum pristupanja 12.08.2017.)

2. Državni zavod za statistiku, Strukturne poslovne statistike, dostupno na: https://www.dzs.hr/ (datum pristupanja 12.08.2017.)

3. Europski parlament i Vijeće EU, Međunarodni standardi financijskog izvještavanja, dostupno na: http://eur-lex.europa.eu/legal-content/HR/TXT/ HTML/?uri=CELEX:02008R1126-20140101\&from=HR (datum pristupanja: 11.08 .2017$.

4. Friedlob, G. T., \& Schleifer, L. L. (2003.), Essentials of Financial Analysis, John Wiley \& Sons, Inc., New Jersey

5. Gibson, C. H. (2011.), Financial Statement Analysis (12th izd.), South-Western, Cengage Learning, Kanada

6. Graham, B., \& Meredith, S. B. (1998.), The Interpretation of Financial Statements: The Classic 1937 Edition, HarperBusiness, New York

7. Holmes, G., Sugden, A., \& Gee, P. (2005.), Interpreting Company Reports and Accounts (9th izd.), Pearson Education Limited, Harlow

8. Horrigan, J. O. (1968.), A Short History of Financial Ratio Analysis, Accounting Review, 43(2), str. 284-294.

9. Odbor za standarde financijskog izvještavanja, Hrvatski standardi financijskog izvještavanja, Odluka o objavljivanju Hrvatskih standarda financijskog izvještavanja, Narodne novine broj 86/2015 od 04.08.2015., dostupno na: http://narodne-novine.nn.hr/search.aspx?upit=hrvatski+standardi+financijskog $+\mathrm{izvje} \% \mathrm{C} 5 \% \mathrm{~A} 1$ tavanja\&naslovi=da\&sortiraj=1\&kategori$\mathrm{ja}=1 \& \mathrm{rpp}=10 \& \mathrm{qtype}=3 \&$ pretraga $=\mathrm{da}$ (datum pristupanja: 11.08.2017.)

10. Orsag, S. (1997.), Vrednovanje poduzeća, Infoinvest d.o.o., Zagreb

11. Palepu, K. G., \& Healy, P. M. (2013.), Business Analysis and Valuation Using Financial statements (5th izd.), South-Western, Cengage Learning, USA

12. Palepu, K. G., Healy, P. M., Bernard, V. L., \& Peek, E. (2007.), Business Analysis and Valuation: IFRS Edition - Test and Cases, Thomson Learning, London

13. Petersen, C. V., \& Plenborg, T. (2012.), Financial Statement Analysis, Pearson Education Limited, Essex, England

14. Pravilnik o strukturi i sadržaju godišnjih financijskih izvještaja, Narodne novine br. 95/2016 od 20.10.2016., dostupno na: http://narodne-novine.nn.hr/ clanci/sluzbeni/2016_10_95_2052.html (datum pristupanja: 11.08.2017.) 
15. Registar godišnjih financijskih izvještaja, Financijska agencija, dostupno na: http://rgfi.fina.hr/JavnaObjava-web/jsp/prijavaKorisnika.jsp (datum pristupanja: 12.08.2017.)

16. Registar poslovnih subjekata Hrvatske gospodarske komore, dostupno na: http://www1.biznet.hr/HgkWeb/do/fullSearchPost (datum pristupanja: 19.07.2017.)

17. Robinson, T. R., Van Greuning, H., Henry, E., Broihahn, M. A. (2009.), International Financial Statement Analysis, John Wiley \& Sons, Inc., New Jersey

18. Solomon, D., \& Muntean, M. (2012.), Assessment of Financial Risk in Firm's Profitability Analysis, Economy Transdisciplinarity Cognition, 15(2), str. 58-67.

19. Statistical office of the European Union - Eurostat, Structural business statistics, dostupno na: http://ec.europa.eu/eurostat/data/database (datum pristupanja: 14.08.2017.)

20. Tintor, J. (2009.), Poslovna analiza, Masmedia, Zagreb

21. Wahlen, J. M., Baginski, S. P., Bradshaw, M. T. (2011.), Financial Reporting, Financial Statement Analysis, and Valuation: A Strategic Perspective (7th izd.), South-Western Cengage Learning, Mason

22. Zakon o računovodstvu, Narodne novine broj 78/2015., 134/2015., 120/2016., dostupno na: http://narodne-novine.nn.hr/clanci/sluzbeni/2015_07_78_1493. html (datum pristupanja: 11.08.2017.)

23. Žager K., K., Mamić Sačer, I., Sever, S., \& Žager L., L. (2009.), Analiza financijskih izvještaja (2. prošireno izd.), Masmedia, Zagreb

24. Žager, K., Mamić Sačer, I., Sever Mališ, S., Ježovita, A. (2017.), Analiza financijskih izvještaja: načela, postupci, slučajevi, treće izmijenjeno i dopunjeno izdanje, Hrvatska zajednica računovođa i financijskih djelatnika, Zagreb 
Lajoš Žager, Ph.D.

University of Zagreb, Faculty of Economics \& Business, Zagreb, Republic of Croatia

lzager@efzg.hr

Ana Ježovita, Ph.D.

University of Zagreb, Faculty of Economics \& Business, Zagreb, Republic of Croatia

ajezovita@efzg.hr

\title{
THE RELEVANCE OF THE ASSETS STRUCTURE FOR THE LIQUIDITY EVALUATION
}

Review

\begin{abstract}
For today's business conditions affected by unfavourable economic environment and general illiquidity it is of great importance to consider the ability of a company to timely provide adequate amount of cash to settle its due liabilities. For every company the most important source of cash inflows is related to its core business, which includes selling goods and services. Because of using the accrual basis in accounting, revenues occur irrespective of whether the money was received at the moment of sale or the sale was carried out on the credit. In case when the sale was carried out on the credit, accounts receivables occur, and in the moment of collecting those receivables, the company receives cash needed to settle its liabilities. That interpretation of the operating cycle emphasise the importance of all current assets categories in cash gap and liquidity management. Next to that, when conducting the assessment it is important to consider size, business activity and location of the company. Traditional liquidity ratios as quick ratio, current ratio and financial stability ratio have great importance in assessing an ability of the company to settle its current liabilities, but using additional dimension of assessing the efficiency of current assets management provides more comprehensive conclusion on the company's financial position.
\end{abstract}

Keywords: assets structure, liquidity, solvency, cash gap

JEL: M41, G32 